\title{
PENGARUH STRUKTUR MODAL TERHADAP PROFITABILITAS DAN NILAI PERUSAHAAN PADA PERUSAHAAN BATUBARA YANG GO-PUBLIC DI INDONESIA
}

\author{
LCA. Robin Jonathan ${ }^{1)}$ \\ Theresia Militina $^{2)}$
}

1) Faculty of Economy, University of 17 Agustus 1945 Samarinda Jalan Juanda 80 Samarinda, Kalimantan Timur, 75124 Indonesia.

2) Faculty of Economy and Business, University of Mulawarman Jalan Kuaro No. 1 Gunung Kelua Samarinda, Kalimantan Timur, 75119, Indonesia. robinjonathan.lca@gmail.com

\begin{abstract}
This study aims to analyze and determine the effect of the projected capital structure in the leverage ratio on profitability and company value in coal companies that go public in Indonesia in 2013-2015 both directly and indirectly.

With the improvement in the selling price of coal today, it is a breath of fresh air for coal mining companies to start their activities. The decision on the proportion between debt and equity is very important. Modigliani and Miller said that the use of debt would be more profitable than the capital itself. The main objective of financial management is to maximize the value of the company. From managed business activities, profits are obtained. The problem is whether the capital structure has a significant effect on profitability and firm value. The development of coal mining companies in Indonesia has good prospects because it is very much needed for the energy industry by generating electricity with coal. The mining and mining service companies listed on the Indonesia Stock Exchange in 2013-2015 were 42 companies and 23 of them were coal mining companies whose financial reports were examined at the same time period. This study uses path analysis with cross section data and secondary data types in the form of financial statements published on the Indonesia Stock Exchange. The results of the study show that directly, capital structure has no significant effect on profitability and has a negative and significant effect on firm value. Profitabitas has no significant effect on firm value. Indirectly, profitability has no significant effect in mediating the relationship of capital structure to firm value.
\end{abstract}

Keywords: Capital structure, profitability, and company value.

\section{PENDAHULUAN}

Indonesia adalah salah satu produsen

batubara terbesar di dunia. Sejak tahun

2005, Indonesia menjadi exporter terdepan

batubara thermal. Beberapa daerah di

Indonesia menyimpan cadangan batubara yang besar seperti daerah Kalimantan

Timur, Kalimantan Selatan dan Sumatera

Selatan. Dalam website $w w w$.

Indexmundi.com digambarkan harga batubara dari tahun 2009-2016 pada tabel 1.

Tabel 1. Harga Batubara

\begin{tabular}{c|c} 
TAHUN & HARGA (USD) \\
\hline 2009 & 77,0 \\
\hline 2010 & 106,0 \\
\hline 2011 & 130,1 \\
\hline 2012 & 103,2
\end{tabular}




\begin{tabular}{l|l}
2013 & 90,6 \\
\hline 2014 & 75,7 \\
\hline 2015 & 62,7 \\
\hline 2016 & 70,1
\end{tabular}

Sumber: www.indexmundi.com., diolah.

Apabila diamati harga batubara dari tahun 2009-2012 yang terus mengalami kenaikan dan turun dari tahun 2012-2015 yang diakibatkan antara lain oleh meningkatnya pemasok dan turunnya permintaan batubara di China, Amerika Serikat dan Negara-negara Eropa. Sukmawati Sukamulja (2017:2013) mengatakan dengan memperhatikan harga batubara acuan Indonesia, Australia, dan Columbia selama tahun 2009-2016 dan harga terlihat mengalami kenaikan pada tahun 2016. Tren kenaikan ini juga dialami oleh Australia dan Columbia dan diprediksi harga batubara acuan akan terus membaik dengan rerata 100 usd/ton. Hal ini akan membawa harapan bagi operasi industri pertambangan batu bara untuk bergerak kembali. Keperluan energi berupa pembangkit listrik tenaga batubara membuat bisnis batubara berkembang dan selalu dibutuhkan masyarakat sampai ditemukan alternative energy yang lebih efisien untuk skala industry. Dengan demikian, bisnis batubara masih menjadi bisnis yang menarik karena keperluan energy pengguna pembangkit tenaga listrik dengan batubara masih amat dibutuhkan karena lebih aman dibandingkan pembangkit tenaga listrik menggunakan tenaga nuklir.

Dengan membaiknya harga jual batubara dewasa ini, merupakan angin segar bagi perusahaan tambang batubara untuk memulai aktivitasnya. Untuk memulai aktivitas usaha tersebut dibutuhkan modal. Sumber modal perusahaan bisa diperoleh dari modal sendiri atau sumber lain yaitu utang. Keputusan terhadap proporsi antara besarnya utang yang digunakan dengan modal sendiri sangatlah penting. Penggunaan utang ada baiknya, apabila selalu berada pada posisi aman. Harus diakui bahwa manusia memiliki sifat yang ambisius untuk memperoleh pendapatan yang tinggi dengan berbagai target tanpa memperhatikan future condition yang sulit diprediksi. Dalam kondisi bisnis bagaimanapun, sebaiknya titik pinjaman tetap pada posisi aman (Irham Fahmi,2015:204) yaitu $40 \%$ dari total asset yang dimiliki. Dengan menggunakan Leverage ratio, rerata (mean) nilai Leverage ratio atas 23 perusahaan tambang batubara tahun 2012-2015 berada pada posisi 0.5711 diatas 0,40 . Ini menunjukkan bahwa kondisi perusahaan 
tambang batubara berada pada posisi rawan gagal bayar.

Tabel 2. Rerata Leverage ratio 23 perusahaan tambang batubaratahun 2012-2015

\begin{tabular}{lrccc}
\hline & $\mathrm{N}$ & Mean & Std. Deviation & Std. Error Mean \\
\hline Debt_TA & 69 & .5711 & .36835 & .04434 \\
Sumber: diolah. & & &
\end{tabular}

Untuk bisa mengambil keputusankeputusan keuangan yang benar, perlu ditentukan tujuan yang harus dicapai. Buchari Alma (2001:23) mengatakan bahwa tujuan utama dari suatu bisnis adalah untuk memenuhi kebutuhan dan keinginan manusia, dari kegiatannya diperoleh keuntungan sehingga pemodal berani memikul resiko menanamkan modalnya dalam kegiatan bisnis. Selanjutnya Rick W. Griffin dan Ronald J. Ebert dalam Sita Wardhani (2006:4) mengatakan bahwa laba merupakan imbalan yang didapat pemilik bisnis dari risiko yang diambil sewaktu menginvestasikan uang dan waktu mereka. Dengan demikian tujuan utama dari bisnis adalah menciptakan keuntungan dari kegiatan bisnisnya.

Secara normatif tujuan keputusan keuangan adalah untuk memaksimumkan nilai perusahaan. Sulaeman Rahman Nidar (2016: 3) berpendapat bahwa nilai perusahaan merupakan harga yang bersedia dibayar oleh calon pembeli apabila perusahaan tersebut dijual. Bagi perusahaan yang menerbitkan saham dipasar modal, harga saham yang diperjual-belikan di bursa merupakan indikator nilai perusahaan. Memaksimumkan nilai perusahaan tidak identik dengan memaksimumkan laba per lembar saham (EPS). Sebaliknya memaksimumkan nilai perusahaanakan identik dengan memaksimumkan laba dalam arti ekonomi. Hal ini disebabkan karena laba ekonomi diartikan sebagai jumlah kekayaan yang bisa dikonsumsi tanpa membuat pemilik kekayaan tersebut menjadi lebih miskin. Eugene F. Brigham (1992:14), Eugene F. Brigham dan Louis C. Gapenski (1990:5) mengatakan "that management's primary goal is stockholder wealth maximization, which translates into maximizing the price of the common stock”.

Bisnis pertambangan adalah kegiatan bisnis galian yang tidak dapat diperbaharui, upaya dalam pencapaian tujuan perusahaan dibutuhkan modal yang cukup besar. Sehingga kegiatan utama dalam pencapaian tujuan manajemen keuangan adalah melakukan tindak efisiensi terhadap penggunaan modal terutama modal asing (utang) yang terdiri atas utang jangka pendek dan utang 
jangka panjang. Penggunaan utang yang tidak efisien, berdampak terhadap nilai perusahaan. Dari uraian diatas, dapat dirumuskan permasalahan: apakah struktur modal perusahaan tambang batubara yang go-public di Indonesia tahun 2013-2015 berpengaruh terhadap profitabilitas dan nilai perusahaan baik secara langsung maupun tidak langsung.

Tujuan dari penelitian ini adalah untuk menganalisis dan mengetahui pengaruh struktur modal perusahaan pertambangan batubara yang go public di Indonesia periode 2013-2015 terhadap profitabilitas dan nilai perusahaan baik secara langsung maupun tidak langsung. Berdasarkan teori yang berkaitan dengan utang, nilai perusahaan dan financial distress, kerangka konsep yang diajukan sebagaimana pada gambar 1 .

\section{Struktur Modal (X)}

Teori struktur modal menjelaskan tentang apakah perubahan komposisi pendanaan akan mempengaruhi nilai perusahaan, apabila keputusan investasi dan kebijakan dividen dipegang konstan. Dalam keadaan pasar modal sempurna dan tidak ada pajak, Modigliani dan Miller (MM) dalam Suad Husnan dan Enny Pudjiastuti (2002 : 297) menunjukkan bahwa struktur modal tidak mempengaruhi nilai perusahaan karena adanya proses arbitrase dimana investor lebih menyukai investasi yang memerlukan dana yang lebih sedikit tetapi memberikan penghasilan bersih yang sama dengan resiko yang sama pula. Dengan mempertimbangkan adanya factor pajak, MM menunjukkan bahwa penggunaan utang akan selalu lebih menguntungkan dibandingkan dengan penggunaan modal sendiri. Hal ini disebabkan oleh sifat tax deductibility of interest payment. Akibatnya atruktur modal yang baik adalah struktur modal yang menggunakan utang. Dengan demikian, sepanjang pembayaran bunga bisa digunakan untuk mengurangi beban pajak, penggunaan utang bermanfaat bagi perusahaan. Ini akan memicu penggunaan utang exterm yang difinalti dengan kebangkrutan, mestinya penggunaan utang akan menurunkan biaya modal perusahaan.

Struktur modal (sebagi variabel independen) diukur dengan ratio leverage yaitu ratio utang terhadap total aktiva yang dimiliki. Perubahan komposisi utang berdampak terhadap harga saham (nilai perusahaan). Masulis (1980) dalam Suad Husnan dan Enny Pudjiastuti (2002 : 318) mengatakan bahwa abnormal return pada hari pengumuman dan sehari setelahnya dari perusahaan yang meningkatkan proporsi penggunaan utang ternyata positif, sedangkan perusahaan yang menurunkan leverage ternyata memperoleh abnormal return yang negative. Abnormal return yang positif 
bagi perusahaan yang meningkatkan manfaat bagi pemodal. proposi penggunaan utang memberikan

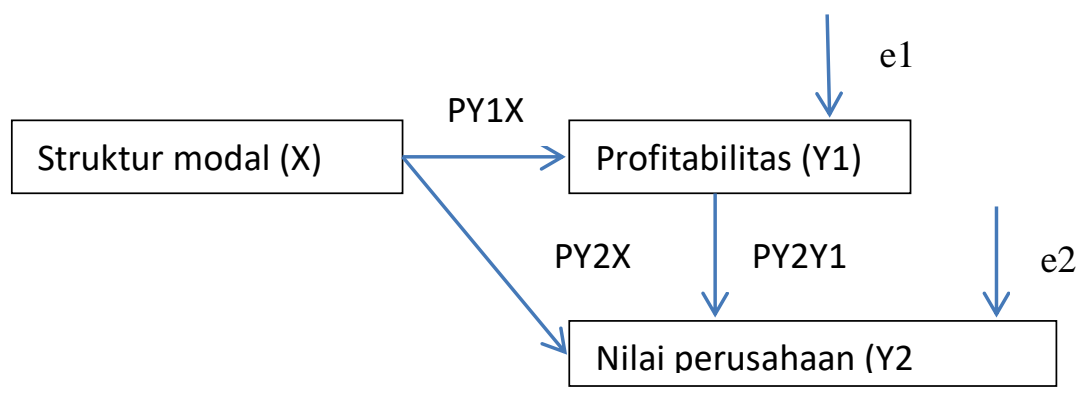

\section{Gambar 1. Kerangka konsep penelitian.}

\section{Profitabilitas (Y1)}

Mendasarkan pada pemikiran bahwa penggunaan utang bisa dibenarkan sejauh diharapkan bisa memberikan tambahan laba operasi (EBIT) yang lebih besar dari bunga yang dibayar. Hal tersebut ditegaskan oleh Bambang Riyanto dalam Suad Husnan dan Enny Pudjiastuti (2002 : 319) bahwa sejauh penggunaan utang diharapkan memberikan rentabilitas ekonomi yang lebih besar dari bunga utang, penggunaan utang dapat dibenarkan. Ini berarti bahwa penggunaan utang diharapkan dapat meningkatkan rentabilitas modal sendiri (return on equity). Ini menunjukkan bagian keuntungan yang menjadi hak pemilik perusahaan. Analisis Rentabilitas ekonomi mengatakan bahwa sejauh tambahan dana tersebut bisa memberikan tambahan laba operasi lebih besar, penggunaan utang bisa dibenarkan. Rentabilitas ekonomi didefinisikan sebagai perbandingan antara laba operasi (EBIT) dengan total kekayaan lebih besar dari biaya utang.

Penggunaan utang pada saat rentabilitas ekonomi lebih besar dari tingkat bunga utang mengakibatkan memperoleh rentabilitas modal sendiri yang lebih besar. Karena rentabilitas modal sendiri menunjukkan bagian keuntungan yang dinikmati oleh pemilik perusahaan, penggunaan utang berarti memberikan bagian keuntungan yang lebih besar kepada pemilik perusahaan. Analisis rentabilitas ekonomi dan rentabilitas modal sendiri menekankan dari sisi profitabilitas penggunaan utang tersebut. Ini berarti bahwa penggunaan utang harus dapat memberikan peningkatan keuntungan bagi perusahaan guna meningkatkan kesejahteraan bagi pemilik.

\section{Nilai perusahaan (Y2)}

Nilai perusahaan (sebagai variabel dependen) diukur dengan harga yang bersedia dibayar oleh calon pembeli apabila perusahaan tersebut dijual. Bagi 
perusahaan yang menerbitkan saham di pasar modal, harga saham yang diperjual belikan dibursa merupakan indicator nilai perusahaan. Makin tinggi nilai perusahaan, semakin besar kemakmuran yang diterima oleh pemilik perusahaan. Modigliani dan Miller dalam Gendro Wiyono dan Hadri Kusuma (2017: 18) menunjukkan bahwa sejauh pembayaran bunga bisa dipergunakan untuk mengurangi beban pajak, penggunaan utang memberi manfaat bagi pemilik perusahaan. Makin tinggi porsi penggunaan utang, makin tinggi nilai perusahaan. Hal ini mendorong perusahaan untuk menggunakan utang dalam meningkatkan nilai perusahaan. Hipotesis yang diajukan pada penelitian ini adalah sebagai berikut:

H1. Utang berpengaruh signifikan terhadap profitabilitas.

H2. Utang berpengaruh signifikan terhadap nilai perusahaan

H3. Utang berpengaruh signifikan terhadap nilai perusahaan melalui profitabilitas.

H4. Profitabilitas berpengaruh signifikan terhadap nilai perusahaan

\section{METODE PENELITIAN}

Perusahaan mining and mining service yang tercatat pada Bursa Efek Indonesia tahun 2013-2015 sebanyak 42 perusahaan dan 23 perusahaan diantaranya adalah perusahaan tambang batubara yang diteliti laporan keuangannya pada kurun waktu yang sama. Penelitian ini menggunakan analisa jalur dengan data cross section dan jenis data sekunder yaitu berupa laporan keuangan yang dipublikasikan pada Bursa Efek Indonesia. Prosedur yang digunakan dalam penenlitian ini, adalah:

1. Statistik dekriptif: Menggambarkan variabel-variabel dari regresi linier yang dibentuk. Peralatan statistic SPSS versi 16.0 untuk menguji pengaruh struktur modal yang diukur dengan leverage ratio (debt/total asset) sebagai variabel independen terhadap profitabilitas yang diukur dengan rentabilitas ekonomi (EBIT/Total asset) dan nilai perusahaan yang diukur dengan harga saham penutupan (ln harga saham) sebagai variabel dependen. Pendekatan analisa jalur digunakan untuk menguji pengaruh langsung dan pengaruh tidak langsung.

2. Uji Normalitas (Suliyanto, 2011:75) dimaksudkan untuk menguji apakah nilai residual yang telah distandarisasi pada model regresi berdistribusi normal. Pengujian ini menggunakan model Kolmogorov-SmirnovZ dengan syarat signifikan $>\alpha=0,05$.

3. Uji Linieritas (Suliyanto, 2011:163) dimaksudkan untuk mengetahui apakah model yang dibuktikan merupakan model benar linier. Pengujian ini 
menggunakan model Lagrange Multiplier (LM Test) dengan membandingkan $\mathrm{X}^{2}$ hitung diperoleh dari nxR ${ }^{2}$ (Gujarati, 2003 dalam Suliyanto, 2011: 112) dengan $\mathrm{X}^{2}$ tabel pada $\alpha=$ 0,05 .

4. Asumsi klasik (Ghozali dan Fuad, 2008) yang paling fundamental dalam analisis multivariate adalah uji normalitas dan multikolinieritas. Olobatuyi (2006) menambahkan linieritas dan autokorelasi. Abram (2006) mengatakan bahwa uji autokorelasi bisa diabaikan apabila data yang digunakan berupa data cross section. Dengan demikian, pada penelitian ini dalam menguji asumsi klasik menggunakan uji multikolinieritas dan uji heteroskedastisitas

a. Uji Multikolieritas (Suliyanto, 2011:81) bertujuan untuk menguji apakah model regresi yang terbentuk ada korelasi yang tinggi atau sempurna diantara variabel independen atau tidak. Jika terdapat korelasi yang tinggi atau sempurna diantara variable independen, model regresi tersebut dinyatakan mengandung gejala multikolinier. Untuk mendeteksi digunakan nilai tolerance dan VIF. Model regresi dikatakan bebas multikolinieritas bilamana nilai tolerance $>0,10$ dan $\mathrm{VIF}<10$. b. Uji Heteroskedatisitas (Suliyanto, 2011:107) bertujuan untuk menguji apakah dalam model regresi terjadi ketidaksamaan variance residual dari pengamatan satu ke pengamatan yang lain. Untuk mendeteksi hal tersebut, digunakan metode White. Model dikatakan bebas Heteroskedatisitas apabila nilai $\mathrm{X}^{2}$ hitung $<\mathrm{X}_{\text {tabel }}^{2}$ pada $\alpha=$ 0,05 .

5. Untuk menguji hipotesis, digunakan uji $\mathrm{F}$, uji $\mathrm{t}$ dan koefisien determinasi $\left(\mathrm{R}^{2}\right)$.

6. Uji Sobel (Suliyanto, 2011:198) digunakan untuk menguji variabel mediasi dengan metode Product of coefficient. Uji variable mediasi dengan metode ini dilakukan dengan menguji kekuatan pengaruh tidak langsung variable independen $(\mathrm{X})$ terhadap variabel dependen (Y2) melalui variable mediasi (Y1) atau menguji signifikansi pengaruh tidak langsung. Dikatakan signifikan sebagai variabel mediasi jika nilai $Z_{\text {hitung }}$ yang diperoleh dari ratio $\mathrm{ab} / \mathrm{S}_{\mathrm{ab}}$ lebih besar dari $\mathrm{Z}_{\text {tabel }}$ pada $\alpha=0,05$.

\section{ANALISA DAN PEMBAHASAN}

Analisa yang digunakan adalah analisa jalur dengan langkah sebagai berikut:

1. Menentukan diagram jalur berdasarkan paradigm hubungan linier. 
Diagram jalur terdiri dari variabel eksogen $\mathrm{X}$ dan variabel endogen $\mathrm{Y} 1$, Y2

2. Menentukan persamaan structural sebagai berikut:

a. Persamaan substruktur 1:

$$
\mathrm{Y} 1=\mathrm{PY} 1 \mathrm{X}+\mathrm{e} 1
$$

b. Persamaan substruktur 2:

$$
\mathrm{Y} 2=\mathrm{PY} 2 \mathrm{X}+\mathrm{PY} 2 \mathrm{Y} 1+\mathrm{e} 2
$$

3. Menganalisa melalui tahapan:

a. Menganalisa persamaan substruktur b. Menganalisa persamaan substruktur 2.

\section{Analisa Persamaan Substruktur 1}

Persamaan substruktur 1:

$\mathrm{Y} 1=\mathrm{PY} 1 \mathrm{X}+\mathrm{e} 1$

Dimana : $\mathrm{Y} 1=$ Profitabilitas, $\mathrm{X}=$ Struktur modal, $\mathrm{P}=$ Beta, $\mathrm{e} 1=$ error.

Untuk mengetahui kelayakan dari suatu model, dilakukan:

1. Uji Normalitas

Uji Normalitas dengan menggunakan model Kolmogorov-SmirnovZ didapat:

Tabel. 3. Uji Normalitas Model Kolmogorov-SmirnovZ

\begin{tabular}{|c|c|c|}
\hline \multirow[b]{2}{*}{$\mathrm{N}$} & \multicolumn{2}{|c|}{ Standardized Residual } \\
\hline & & 69 \\
\hline \multirow[t]{2}{*}{ Normal Parameters ${ }^{\mathrm{a}}$} & Mean & .0000000 \\
\hline & Std. Deviation & .99261983 \\
\hline \multirow{3}{*}{$\begin{array}{l}\text { Most Extreme } \\
\text { Differences }\end{array}$} & Absolute & .119 \\
\hline & Positive & .119 \\
\hline & Negative & -.118 \\
\hline \multicolumn{2}{|c|}{ Kolmogorov-Smirnov Z } & .984 \\
\hline \multicolumn{2}{|l|}{ Asymp. Sig. (2-tailed) } & .287 \\
\hline
\end{tabular}

One-Sample Kolmogorov-Smirnov Test

a. Test distribution is Normal.

Asymp sig menunjukkan nilai 0.287 >

0.05, nilai residual terstandarisasi menyebar secara normal.
2. Uji Linieritas.

Uji Linieritas dengan menggunakan model Lagrange Multiplier (LM Test) didapat:

Tabel 4. Uji Linieritas Model Lagrane Multiplier

\begin{tabular}{|c|c|c|c|c|}
\hline Model & $\mathrm{R}$ & R Square & Adjusted R Square & Std. Error of the Estimate \\
\hline 1 & $.236^{\mathrm{a}}$ & .056 & .041 & .16141338 \\
\hline
\end{tabular}
Model Summary

a. Predictors: (Constant), X_sqr

Nilai $X^{2}$ hitung $=0,056 \times 69=3.864<X_{\text {tabel }}^{2}$ 3. Regresi Linier.

89.39, berarti model regresi yang

a. Hubungan antar variabel $(n=69)$

digunakan benar linier.

Tabel 5. Hubungan Antar Variabel Dalam Model Persamaan Substruktur 1 


\section{Correlations}

\begin{tabular}{llrrr}
\hline & & Y1 & X \\
\hline Pearson Correlation & Y1 & 1.000 & .041 \\
\cline { 2 - 5 } & $\mathrm{X}$ & .041 & 1.000 \\
\hline \multirow{2}{*}{ Sig. (1-tailed) } & $\mathrm{Y} 1$ & .368 & .368 \\
\cline { 2 - 4 } & $\mathrm{X}$ & 69 &. \\
\hline $\mathrm{N}$ & $\mathrm{Y} 1$ & 69 & 69 \\
\cline { 2 - 4 } & $\mathrm{X}$ & & 69
\end{tabular}

Variabel X berhubungan tidak signifikan terhadap Y1.

b. Koefisien Derterminasi $\left(\mathrm{R}^{2}\right)$.

Koefisien Determinasi $\left(\mathrm{R}^{2}\right)$ mengukur seberapa jauh kemampuan model dalam menjelaskan keberadaan variabel dependen.

Tabel 6. Koefisien Determinasi $\left(\mathbf{R}^{2}\right)$ Persamaan Substruktur 1

Model Summary ${ }^{b}$

\begin{tabular}{|l|r|r|r|r|}
\hline Model & R & R Square & Adjusted R Square & \multicolumn{1}{|c|}{ Std. Error of the Estimate } \\
\hline 1 & $.041^{\mathrm{a}}$ & .002 & -.013 & .16609 \\
\hline
\end{tabular}

a. Predictors: (Constant), $\mathrm{X}$

Dependent Variable: Y1

Hasil analisis regresi diperoleh nilai $\mathrm{R}^{2}=$ .002 ini berarti model penelitian mampu menjelaskan keberadaan variabel dependen sebesar $0,2 \%$ dan sisanya $97 \%$ dijelaskan oleh variabel diluar model. c. Uji F.

Uji $F$ menjelaskan kemampuan variabel independen secara simultan menjelaskan keberadaan variabel dependen.

Tabel 7. Uji F

\begin{tabular}{|c|c|c|c|c|c|c|}
\hline \multicolumn{7}{|c|}{ ANOVA $^{b}$} \\
\hline Model & & Sum of Squares & Df & Mean Square & $\mathrm{F}$ & Sig. \\
\hline \multirow[t]{3}{*}{1} & Regression & .003 & 1 & .003 & .115 & $.736^{\mathrm{b}}$ \\
\hline & Residual & 1.848 & 67 & .028 & & \\
\hline & Total & 1.851 & 68 & & & \\
\hline
\end{tabular}

a. Predictors: (Constant), $\mathrm{X}$

Dependent Variable: Y1

Hasil analisa regresi diperoleh nilai $\mathrm{F}=$ $0.115<3.978$ ini berarti bahwa model yang digunakan tidak dapat menjelaskan secara signifikan keberadaan variabel dependen.

\section{d. Uji t}

Uji $\mathrm{t}$ menjelaskan kemampuan variabel independen secara partial menjelaskan keberadaan variabel dependen.

Tabel 8. Uji t

Coefficients $^{\mathrm{a}}$ 


\begin{tabular}{|c|c|c|c|c|c|c|c|c|}
\hline \multirow[b]{2}{*}{ Model } & & \multicolumn{2}{|c|}{$\begin{array}{l}\text { Unstandardized } \\
\text { Coefficients }\end{array}$} & \multirow{2}{*}{$\begin{array}{c}\begin{array}{c}\text { Standardized } \\
\text { Coefficients }\end{array} \\
\text { Beta }\end{array}$} & \multirow[b]{2}{*}{$\mathrm{T}$} & \multirow[b]{2}{*}{ Sig. } & \multicolumn{2}{|c|}{ Collinearity Statistics } \\
\hline & & $\mathrm{B}$ & Std. Error & & & & Tolerance & VIF \\
\hline \multirow[t]{2}{*}{1} & (Constant) & .044 & .037 & & 1.193 & .237 & & \\
\hline & $X$ & .019 & .055 & .041 & .339 & .736 & 1.000 & 1.00 \\
\hline
\end{tabular}

a. Dependent Variable: Y1

Hasil analisa regresi ditemukan bahwa variabel $\mathrm{X}$ secara partial berpengaruh signifikan terhadap Y1. Hasil pengujian hipotesis menunjukkan bahwa hipotesis ke
1 yang diajukan berhasil ditolak. Berdasarkan hasil regresi persamaan substruktur 1, dapat digambarkan sebagai berikut:

e. Pengujian Hipotesis.

Tabel 9. Pengujian Hipotesis Model Persamaan Substruktur 1

\begin{tabular}{lcccccc} 
Variabel Dependen & Variabel Independen & $\mathrm{P}$ & $\mathrm{T}$ & Sig.0.05 & Keterangan & Hipotesis ke: \\
\hline $\mathrm{Y} 1$ & $\mathrm{X}$ & .041 & .339 & .736 & $\begin{array}{c}\text { Tidak } \\
\text { Signifikan }\end{array}$ & 1. Ditolak \\
\hline
\end{tabular}

$\mathrm{R}^{2}=0,002$

$\mathrm{F}_{\mathrm{h}}=0,115$

Sig $=0,736$

Sumber: Hasil analisis regresi.

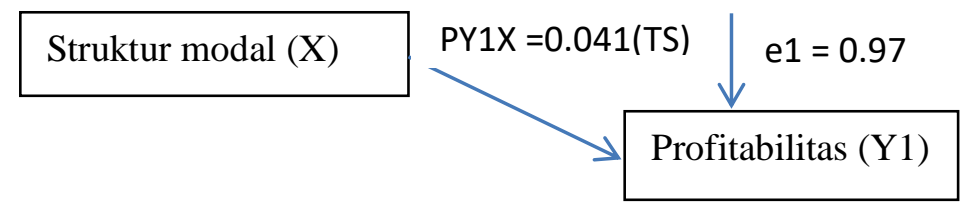

Gambar 2. Diagram Jalur Persamaan substuktur 1

b. Analisa Persamaan Substruktur 2

Persamaan substruktur 2:

$$
\mathrm{Y} 2=\mathrm{PY} 2 \mathrm{X}+\mathrm{PY} 2 \mathrm{Y} 1+\mathrm{e} 1
$$

Dimana $: \mathrm{Y} 2=$ Nilai perusahaan, $\mathrm{Y} 1=$

Profitabilitas, $\mathrm{X}=$ Struktur modal, $\mathrm{P}=$

Beta, e $1=$ error
Untuk mengetahui kelayakan dari suatu model, dilakukan:

1. Uji Normalitas

Uji Normalitas dengan menggunakan model Kolmogorov-SmirnovZ didapat:

Tabel. 10. Uji Normalitas Model Kolmogorov-SmirnovZ One-Sample Kolmogorov-Smirnov Test

\begin{tabular}{llr}
\hline & & Standardized Residual \\
\hline $\mathrm{N}$ & & 69 \\
\hline Normal Parameters $^{\mathrm{a}}$ & Mean & .0000000 \\
\cline { 2 - 3 } & Std. Deviation & .98518437 \\
\hline Most Extreme & Absolute & .092 \\
\cline { 2 - 3 } Differences & Positive & .092
\end{tabular}




\begin{tabular}{|c|c|}
\hline Negative & -.071 \\
\hline Kolmogorov-Smirnov Z & .762 \\
\hline Asymp. Sig. (2-tailed) & .607 \\
\hline
\end{tabular}

a. Test distribution is Normal.

Asymp sig menunjukkan nilai.0.607 > 0.05 , nilai residual terstandarisasi menyebar secara normal.
2. Uji Linieritas.

Uji Linieritas dengan menggunakan model

Lagrange Multiplier (LM Test) didapat:

Tabel 11. Uji Linieritas Model Lagrane Multiplier

Model Summary

\begin{tabular}{|c|c|c|c|c|}
\hline Model & $\mathrm{R}$ & R Square & Adjusted R Square & Std. Error of the Estimate \\
\hline 1 & $.206^{\mathrm{a}}$ & .042 & .013 & 1.40936643 \\
\hline
\end{tabular}

a. Predictors: (Constant), X_Sqr, Y1_Sqr

Nilai $X^{2}$ hitung $=0.042 \times 69=2.898<X^{2}$ tabel 89.39 , berarti model regresi yang digunakan benar linier.

\section{Uji Asumsi Klasik}

a. Uji Multikolinieritas

Tabel 12. Uji Multikolinieritas

Coefficients $^{\mathrm{a}}$

\begin{tabular}{|c|c|c|c|c|c|c|c|c|}
\hline \multirow[b]{2}{*}{ Model } & & \multicolumn{2}{|c|}{$\begin{array}{c}\text { Unstandardized } \\
\text { Coefficients }\end{array}$} & \multirow{2}{*}{$\begin{array}{c}\begin{array}{c}\text { Standardized } \\
\text { Coefficients }\end{array} \\
\text { Beta } \\
\end{array}$} & \multirow[b]{2}{*}{$\mathrm{t}$} & \multirow[b]{2}{*}{ Sig. } & \multicolumn{2}{|c|}{ Collinearity Statistics } \\
\hline & & $\mathrm{B}$ & Std. Error & & & & Tolerance & VIF \\
\hline 1 & (Constant) & 7.279 & .325 & & 22.403 & .000 & & \\
\hline & Y1 & -1.751 & .475 & -.411 & -3.690 & .000 & .998 & 1.002 \\
\hline & $\bar{X}$ & 1.245 & 1.059 & .131 & 1.176 & .244 & .998 & 1.002 \\
\hline
\end{tabular}

a. Dependent Variable: Y2

Nilai Tolerance untuk masing-masing variabel bebas $>, 10$ dan nilai VIF $<10$. Ini berarti

b. Uji Heteroskedastisitas variabel bebas yang digunakan bebas dari multikolinieritas.

Tabel 13. Uji Heteroskedastisitas

Model Summary ${ }^{\text {b }}$

\begin{tabular}{lrrrr}
\hline Model & \multicolumn{1}{l}{ R } & \multicolumn{2}{c}{ R Square } & \multicolumn{2}{c}{ Adjusted R Square } & \multicolumn{2}{l}{ Std. Error of the Estimate } \\
\hline 1 & $.292^{\mathrm{a}}$ & .085 & .012 & 2.631175 \\
\hline
\end{tabular}

a. Predictors: (Constant), X_Y1, Y1, X_Sqr, Y1_Sqr, X

b. Dependent Variable: U2

Nilai $X_{\text {hitung }}^{2}=0.085 \times 69=58.65<X_{\text {tabel }}^{2}$

89,39 maka model regresi yang digunakan bebas dari heteroskastisitas.
4. Regresi Linier Berganda.

a. Hubungan antar variabel $(n=69)$

Tabel 14. Hubungan Antar Variabel Dalam Model Persamaan Substruktur 2 Correlations 


\begin{tabular}{llrrrr} 
& & $\mathrm{Y} 2$ & $\mathrm{X}$ & $\mathrm{Y} 1$ \\
\hline \multirow{2}{*}{ Pearson Correlation } & $\mathrm{Y} 2$ & 1.000 & -.406 & .114 \\
\cline { 2 - 5 } & $\mathrm{X}$ & -.406 & 1.000 & .041 \\
\cline { 2 - 5 } Sig. (1-tailed) & $\mathrm{Y} 1$ & .114 & .041 & 1.000 \\
\cline { 2 - 5 } & $\mathrm{Y} 2$ &. & .000 & .176 \\
\cline { 2 - 5 } & $\mathrm{X}$ & .000 & .368 & .368 \\
\hline $\mathrm{N} 1$ & $\mathrm{Y} 2$ & .176 & 69 &. \\
\cline { 2 - 5 } & $\mathrm{X}$ & 69 & 69 & 69 \\
\cline { 2 - 5 } & $\mathrm{Y} 1$ & 69 & 69 & 69
\end{tabular}

Variabel $\mathrm{X}$ berhubungan negative dan signifikan terhadap $\mathrm{Y} 2$, variabel $\mathrm{X}$ berhubungan tidak signifikan terhadap Y1. dan variabel Y1 berhubungan tidak signifikan terhadap Y2 b. Koefisien Derterminasi $\left(\mathrm{R}^{2}\right)$.

Koefisien Determinasi $\left(\mathrm{R}^{2}\right)$ mengukur seberapa jauh kemampuan model dalam menjelaskan keberadaan variabel dependen.

Tabel 15. Koefisien Determinasi $\left(\mathbf{R}^{2}\right)$ Persamaan Substruktur 2

Model Summary

\begin{tabular}{|c|c|c|c|c|}
\hline Model & $\mathrm{R}$ & R Square & Adjusted R Square & Std. Error of the Estimate \\
\hline 1 & $.426^{\mathrm{a}}$ & .182 & .157 & 1.44010 \\
\hline
\end{tabular}

a. Predictors: (Constant), X, Y1

Hasil analisis regresi diperoleh nilai $\mathrm{R}^{2}=$ ,131 ini berarti model penelitian yang diajukan mampu menjelaskan keberadaan variabel dependen sebesar $13,1 \%$ dan sisanya $93.22 \%$ dijelaskan oleh variabel diluar model.

\section{c. Uji F.}

Uji F menjelaskan kemampuan variabel independen secara simultan menjelaskan keberadaan variabel dependen.

Tabel 16. Uji F

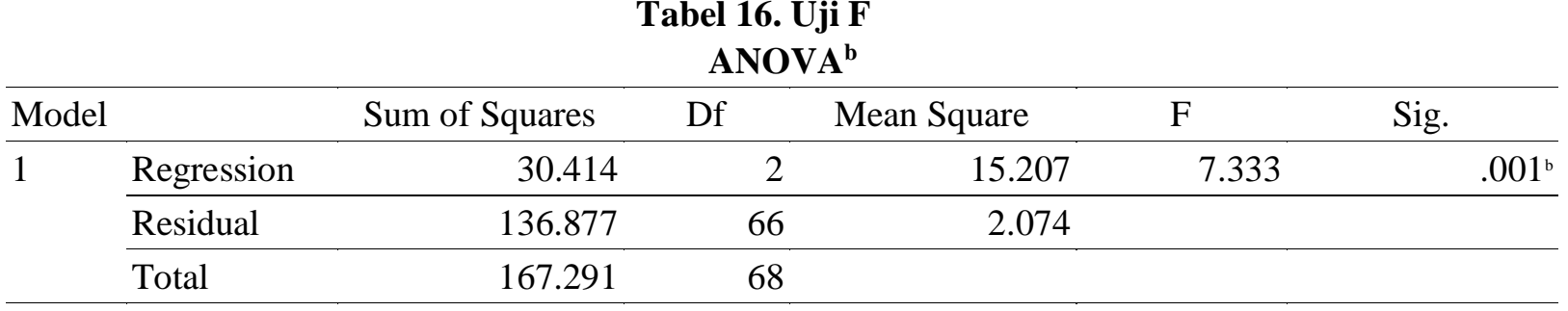

a. Predictors: (Constant), X, Y1

b. Dependent Variable: Y2

Hasil analisa regresi diperoleh nilai $\mathrm{F}=$ $7.333>3.978$ ini berarti bahwa model yang digunakan dapat menjelaskan secara signifikan keberadaan variabel dependen. d. Uji t 
Uji t menjelaskan kemampuan variabel keberadaan variabel dependen. independen secara partial menjelaskan

Tabel 17. Uji t

Coefficients $^{\mathrm{a}}$

\begin{tabular}{|c|c|c|c|c|c|c|c|c|}
\hline \multirow[b]{2}{*}{ Model } & & \multicolumn{2}{|c|}{$\begin{array}{l}\text { Unstandardized } \\
\text { Coefficients }\end{array}$} & \multirow{2}{*}{$\begin{array}{c}\text { Standardized } \\
\text { Coefficients }\end{array}$} & \multirow[b]{2}{*}{$\mathrm{t}$} & \multirow[b]{2}{*}{ Sig. } & \multicolumn{2}{|c|}{ Collinearity Statistics } \\
\hline & & B & Std. Error & & & & Tolerance & VIF \\
\hline 1 & (Constant) & 7.279 & .325 & & 22.403 & .000 & & \\
\hline & $X$ & -1.751 & .475 & -.411 & -3.690 & .000 & .998 & 1.002 \\
\hline & $\mathrm{Y} 1$ & 1.245 & 1.059 & .131 & 1.176 & .244 & .998 & 1.002 \\
\hline
\end{tabular}

a. Dependent Variable: Y2

Hasil analisa regresi ditemukan bahwa variabel $\mathrm{X}$ secara partial berpengaruh negative dan signifikan terhadap $\mathrm{Y} 2$.
Variabel Y1 berpengaruh tidak signifikan terhadap Y2.

e. Pengujian Hipotesis.

Tabel 18. Pengujian Hipotesis Model Persamaan Substruktur 2

$\begin{array}{llllll}\text { Variabel Variabel } & \mathrm{P} & \mathrm{T} & \text { Sig. 0,05 } & \text { Keterangan } & \text { Hipotesis ke: }\end{array}$

Dependen Independen

\begin{tabular}{lcccccc}
\hline $\mathrm{Y} 2$ & $\mathrm{X}$ & -.411 & -3.690 & .000 & Signifikan & 2. Diterima \\
\hline $\mathrm{R}^{2}=.182$ & $\mathrm{Y} 1$ & .131 & 1.176 & .244 & Tidak Signifikan & 4. Ditolak \\
\hline $\mathrm{F}_{\mathrm{h}}=7.333$ & & & & & & \\
\hline
\end{tabular}

$\mathrm{Sig}=.001$

Sumber: Hasil analisis regresi.

Hasil pengujian hipotesis menunjukkan berhasil ditolak. Berdasarkan hasil regresi bahwa hipotesis ke 2 yang diajukan persamaan substruktur 2, dapat berhasil diterima dan hipotesis ke 4 digambarkan sebagai berikut:

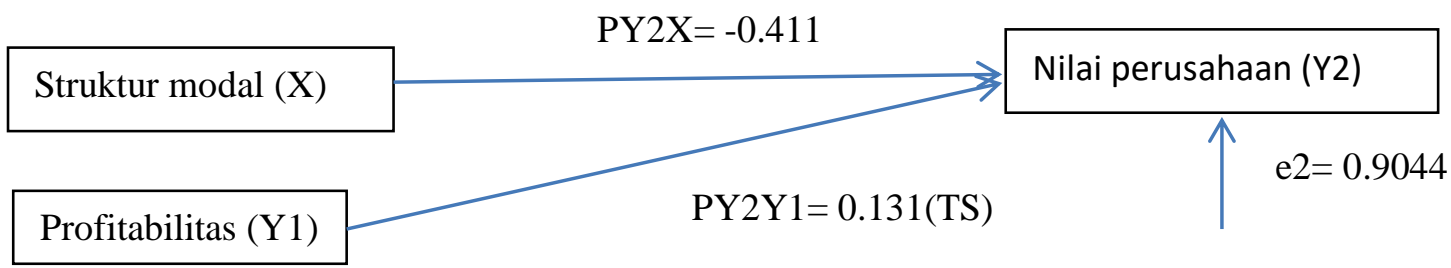

Gambar 3. Diagram Jalur Persamaan substuktur 2

5. Uji Sobel model Product of Coefficient, diketahui signifikansi pengaruh tidak langsung sebagai berikut:
1. Hubungan tidak langsung terhadap Y2 melalui Y1. Model Product of Coefficient :

$$
\begin{aligned}
& \mathrm{Sab}=\left(\mathrm{b}^{2} \mathrm{sa}^{2}+\mathrm{a}^{2} \mathrm{sb}^{2}+\mathrm{sa}^{2} \mathrm{sb}^{2}\right)^{1 / 2}=0.092 \\
& \mathrm{Z}=\mathrm{ab} / \mathrm{Sab} \\
& \quad=0.0237 / 0.092
\end{aligned}
$$




$$
=0.257
$$

Nilai $Z_{\text {hitung }}=0.257<Z_{.05}=1.96$. maka variabel Y1 tidak berpengaruh signifikan dalam memediasi hubungan kausal $\mathrm{X}$ terhadap Y2

\section{Tabel 19. Pengujian Hipotesis}

\begin{tabular}{cccc} 
Variabel & Nilai Uji Z pada $\alpha=.05$ & Signifikansi & Hipotesis ke 3 \\
\hline X->Y1->Y2 & $0.257<1.96$ & Tidak Signifikan & Ditolak \\
Sumber: Diolah dari hasil regresi. & &
\end{tabular}

Sumber: Diolah dari hasil regresi.

Tabel 19 menunjukkan bahwa: Pengaruh langsung, pengaruh profitabilitas tidak berpengaruh signifikan dalam memediasi hubungan kausal struktur modal terhadap nilai perusahaan, Hipotesis 3 berhasil ditolak. tidaklangsung dan pengaruh total dari masing-masing variabel independen terhadap variabel dependen ditunjukkan

2. Pengaruh langsung, Pengaruh tidak langsung dan Pengaruh total.

Tabel 20. Pengaruh Langsung, Pengaruh Tidak Langsung dan Pengaruh Total.

\begin{tabular}{ccccc}
$\begin{array}{c}\text { Pengaruh antar } \\
\text { variabel }\end{array}$ & $\begin{array}{c}\text { Pengaruh } \\
\text { langsung }\end{array}$ & $\begin{array}{c}\text { Pengaruh tidak } \\
\text { langsung melalui Y1 }\end{array}$ & Pengaruh total & Keterangan \\
\hline $\mathrm{X}->\mathrm{Y} 1$ & $0.041(\mathrm{TS})$ & & \\
\hline $\mathrm{X}->\mathrm{Y} 2$ & $-0.411(\mathrm{~S})$ & $0.0054(\mathrm{TS})$ & -0.4056 \\
\hline $\mathrm{Y} 1->\mathrm{Y} 2$ & $0.131(\mathrm{TS})$ & &
\end{tabular}
Sumber: Diolah dari hasil regresi

Dari uraian diatas, dapat digambarkan diagram dari keputusan investasi, keputusan pendanaan sebagai variabel exogenous dan biaya modal perusahaan dan financial distress sebagai variabel endogenous seperti gambar 4 . Berdasarkan diagram jalur diatas, dapat diuraikan sebagai berikut:

1. Pengaruh langsung dari variabel exogenous terhadap variabel endogenous.

a. Struktur modal dan profitabilitas.

Struktur modal yang diukur dengan leverage ratio berpengaruh positif dan tidak signifikan terhadap profitabilitas yang diukur dengan rentabilitas ekonomi. Ini berarti bahwa penambahan utang akan diikuti dengan penambahan laba operasi, namun penambahan tersebut tidak signifikan. Peningkatan penggunaan utang, akan diikuti dengan peningkatan profitabilitas perusahaan. Namun penggunaan utang pada perusahaan tambang batubara berpengaruh tidak signifikan terhadap profitabilitas. Bambang Riyanto mengingatkan bahwa sejauh penggunaan utang diharapkan memberikan tambahan rentabilitas ekonomi yang lebih besar dari bunga utang, penggunaan utang tersebut dapat dibenarkan. Penggunaan utang pada perusahaan tambang batubara 
perlu untuk mendapatkan perhatian lebih.

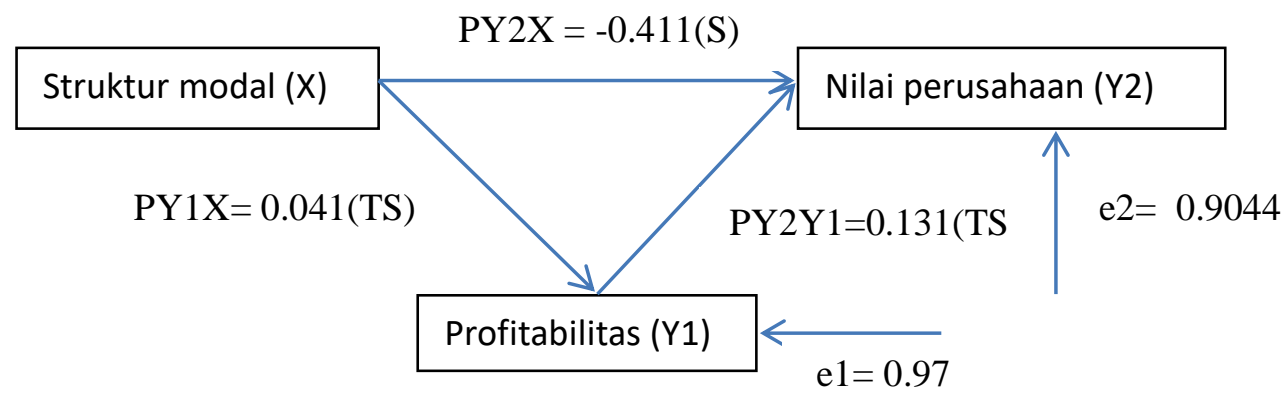

Gambar 4. Diagram Jalur Persamaan 1 dan 2

b. Struktur modal dan nilai perusahaan.

Struktur modal yang diukur dengan leverage ratio berpengaruh negative dan signifikan terhadap nilai perusahaan yang diukur dengan harga saham penutup. Ini berarti bahwa penambahan utang berpengaruh signifikan terhadap penurunan harga saham yaitu sebesar $41,10 \%$. Ini berarti bahwa tingginya penggunaan utang berdampak signifikan terhadap turunnya harga saham. Hal ini menunuukkan bahwa penggunaan utang pada perusahaan tambang batubara sudah optimal. Dengan demikian perusahaan tambang batubara sebagai penggunaan utang harus berhati-hati didalam pengambilan keputusan pendanaan terutama dana external karena penambahan utang akan berdampak terhadap risiko dan umumnya investor tidak menyukai risiko (risk averse). Investor baru bersedia mengambil suatu kesempatan investasi yang lebih berisiko kalau memperoleh tingkat keuntungan yang lebih tinggi.

c. Profitabilitas dan nilai perusahaan.

Profitabilitas yang diukur dengan rentabilitas ekonomi berpengaruh tidak signifikan terhadap nilai perusahaan yang diukur dengan harga saham penutup. Ini berarti bahwa kemampuan perusahaan dalam meningkatkan laba operasi berpengaruh $13,10 \%$ dan tidak signifikan terhadap peningkatan harga saham. Ini menunjukkan bahwa makin meningkatnya kemampuan perusahaan tambang batubara dalam perolehan laba operasi dari total asset yang dimiliki berpengaruh tidak signifikan terhadap kenaikan harga saham.

2. Pengaruh tidak langsung dari variabel exogenous terhadap variabel endogenous.

Struktur modal, nilai perusahaan dan profitabilitas. 
Struktur modal secara langsung berpengaruh negative $41,10 \%$ dan signifikan terhadap nilai perusahaan. Profitabilitas sebagai variable mediasi berpengaruh $0,54 \%$ dan tidak signifikan. Ini berarti bahwa penambahan utang berpengaruh negative dan signifikan terhadap penurunan harga saham pada perusahaan tambang batubara. Jika penambahan utang dipinalti dengan kemampuan perusahaan memperoleh laba operasional, berdampak negative $40,56 \%$ terhadap nilai perusahaan.

\section{KESIMPULAN}

1. Penambahan utang pada perusahaan tambang batubara berpengaruh tidak signifikan terhadap peningkatan kemampuan perusahaan dalam perolehan laba operasional dari asset yang digunakan.

2. Penambahan utang pada perusahaan tambang batubara berpengaruh signifikan terhadap penurunan harga saham.

3. Kemampuan perusahaan tambang batubara dalam meningkatkan laba operasional dari asset yang dimiliki berpengaruh tidak signifikan terhadap kenaikan harga saham

4. Profitabilitas tidak berpengaruh signifikan dalam memediasi hubungan struktur modal terhadap nilai perusahaan.

\section{SARAN}

1. Bagi peneliti selanjutnya dapat menggunakan melakukan penelitian lebih mendalam berkaitan dengan struktur modal, profitabilitas dan nilai perusahaan.

2. Bagi pelaku bisnis dalam mengambil keputusan investasi, tidak hanya memperhatikan kemampuan perusahaan memperoleh laba tetapi juga hendaknya memperhatikan kemampuan perusahaan menggunakan dana extern.

\section{DAFTAR PUSTAKA}

Abrams, Jat H, 2010. Quantitative Business Valuation: A Mathematical Approach for Today's Professional, Second Edition, John Wiley \& Sons. Inc.

Alma, Buchari, 2001. Pengantar Bisnis, Edisi Revisi, Penerbit ALFABETE, Bandung.

Brigham, Eugene F., 1992. Fundamentals of Financial Management, Sixth Edition, The Dryden Press, Orlondo, Florida.

Louis C. Gapenski, 1990. Intermediate Financial Management, Third Edition, The Dryden Press, San Francisco.

Griffin, Rick W. dan Ronald J. Ebert, 2007. BISNIS, alih Bahasa Sita Wardhani, Edisi kedelapan, Jilid 1 Penerbit Erlangga, Jakarta. 
Ghozali, Imam, 2012. Partial Least Square: Konsep, Teknik dan Aplikasi Menggunakan Program Smart PLS 2.0M, Badan Penerbit Universitas Diponegoro, Semarang.

Halim, Abdul, 2015. Manajemen Keuangan Bisnis, Edisi Pertama, Mitra Wacana Media, Jakarta.

Hanafi, Mamduh M., dan Abdul Halim, 2016. Analisis Laporan Keuangan, Edisi Kelima, Penerbit UPP STIM YKPN, Yogyakarta.

Hery, 2017. Kajian Riset Akuntansi, Penerbit PT. Grasindo, Jakarta.

Husnan, Suad dan Enny Pudjiastuti, 2002. Dasar-Dasar Manajemen Keuangan, Edisi Ketiga, UPP AMP YKPN, Yogyakarta.

Fahmi, Irham, 2015. Analisis Laporan Keuangan, Penerbit ALFABETA Bandung.

Olobatuyi, Moses E, 2006.. A User's
Guide to Path Analysis, Lanham, Maryland: University Press of Amarica Inc.

Pardede Ratlan dan Renhard Manurung, 2014. Analisis Jalur (Path Analysis) Teori dan Aplikasi dalam Riset Bisnis, Penerbit Rineka Cipta, Jakarta.

Rahman Nidar, Sulaeman, 2016. Manajemen Keuangan Perusahaan Modern, Cetakan I, Penerbit Pustaka Reka Cipta, Jakarta.

Sukamulija, Sukmawati, 2017. Pengantar Pemodelan Keuangan dan Analisis Pasar Modal, Penerbit ANDI, Yogyakarta.

Suliyanto, 2011. Ekometrika Terapan: Teori dan Aplikasi dengan SPSS, Penerbit ANDI Yogyakarta.

Wiyono, Gendro dan Hadri Kusuma, 2017. Manajemen Keuangan Lanjutan, Edisi Pertama, UPP AMP YKPM Yogyakarta. 